\title{
COMMUNICATION
}

\section{Mitochondrial inner membrane in Hypothyroidism ${ }^{1}$}

\begin{abstract}
Inner membrane vesicles obtained from the liver mitochondria of hypothyroid and normal rats were compared. In the vesicles from hypothyroid rats the rate of ATP synthesis at $30^{\circ} \mathrm{C}$ is $35-50 \%$ less than the normal rate. The Arrhenius profile for phosphorylation by such vesicles lacks the discontinuity at $21^{\circ} \mathrm{C}$ that is seen with vesicles from normal rats; at temperatures below about $9^{\circ} \mathrm{C}$ the rate of phosphorylation by vesicles from hypothyroid rats is not lower than normal. The phospholipids of hypothyroid vesicles contain higher mole fractions of 18:2 (linoleic), 18:3 (linolenic or $\gamma$ linolenic), and 20:3 (eicosatrienoic) and lower fractions of 20:4 (arachidonic), 22:3 (docosatrienoic), and 22:4 (docosatetraenoic); the unsaturation index, mainly due to $20: 4$, is $10 \%$ less than in normal vesicles. Injecting hypothyroid rats with $\mathrm{L}$-thyroxine 3 days before preparation of vesicles corrects the relative contents of these unsaturated fatty acids as well as the Arrhenius profile and also increases the phosphorylation rate at $30^{\circ} \mathrm{C}$. Respiration and cytochrome $a$ content do not differ for membrane vesicles prepared from livers of rats in the various thyroid states. A metabolic defect in unsaturated fatty acid metabolism in hypothyroidism may be involved in the function of the inner mitochondrial membrane.
\end{abstract}

The rates of phosphorylation of added ADP and respiration in State 3 are about proportionately decreased in intact mitochondria from the livers of hypothyroid rats as compared with mitochondria from normal rats $(1,2)$. In mitochondrial inner membranes phosphorylation is slow but respiration is normal in hypothyroids (Table I). Inner membrane vesicles prepared by digitonin extractions (4) of mitochondria from hypothyroid rats phosphorylate added ADP at only half the normal rate at $30^{\circ} \mathrm{C}$, but oxidize $\beta$-hydroxybutyrate at an undiminished rate. The intactness of the electron transport system is further shown by the similar cytochrome spectra and absorbances in vesicles from hypothyroid and normal rats; cytochrome $a$ contents are shown in Table I. Hypothyroid rats were injected intraperitoneally with $0.5 \mu \mathrm{g}$ of L-thyroxine ${ }^{2}\left(\mathrm{LT}_{4}\right) / \mathrm{g}$ body weight 3 days before killing, a dosage used by Tata (8) to eliminate unphysiological hormone effects. The $\mathrm{LT}_{4}$ pretreatment restores the rate of phospho-

1 This work was supported by grants from the National Institutes of Health, (No. AM13564-03), The John A. Hartford Foundation and the National Science Foundation (No. GB42256). The data were taken from a dissertation submitted by Y.-D. I. Chen to The University of Michigan in partial fulfillment of the requirements for the degree of Doctor of Philosophy. Y.-D. I. Chen was supported in part by a National Institutes of Health grant (No. 5-SO1RR05373-13).

${ }^{2}$ Abbreviation used: $\mathrm{LT}_{4}$, L-thyroxine. rylation at $30^{\circ} \mathrm{C}$ to normal levels without changing vesicle respiration or cytochrome content

The defect in phosphorylation at $30^{\circ} \mathrm{C}$ is one aspect of an abnormal temperature dependence in the inner membranes prepared from the liver mitochondria of hypothyroid rats (Fig. 1). In such membrane vesicles the Arrhenius plot is linear up to about $30^{\circ} \mathrm{C}$. In similarly prepared vesicles from normal rats a transition occurs at $21^{\circ} \mathrm{C}$. In intact liver mitochondria from normal rats, discontinuities in Arrhenius plots of external ADP phosphorylation and partial reactions of oxidative phosphorylation are common to the entire respiratory chain and occur at two temperature ranges, $15-19^{\circ} \mathrm{C}$ and $25-30^{\circ} \mathrm{C}(9)$, whereas other investigators find only one inflection for $\mathrm{P}_{\mathrm{i}}$-ATP exchange or ATP-ADP exchange at 16 $18^{\circ} \mathrm{C}(10)$ and for succinate oxidation in State 3 at $21-24^{\circ} \mathrm{C}$ (11). Figure 1 shows that in membrane vesicles obtained from hypothyroid rats the energy of activation of phosphorylation below $21^{\circ} \mathrm{C}$ is less than that in vesicles from normal rats, and above $21^{\circ} \mathrm{C}$ it is greater. Below about $9^{\circ} \mathrm{C}$ there are no significant differences between the phosphorylation in both groups of vesicles. In the Arrhenius profiles for phosphorylation by vesicles from $\mathrm{LT}_{4}$-pretreated hypothyroid rats (not shown in Fig. 1) there is a discontinuity at about $21^{\circ} \mathrm{C}$, and the activation energies are restored toward normal values; the rate of phosphorylation at $30^{\circ} \mathrm{C}$ (Table I) is thus restored to normal levels.

The thermal responses of membrane-dependent processes (12) and oxidative phosphorylation $(13,14)$ 
TABLE I

Oxidative Phosphorylation and Cytochrome $a$ Content in InNer Membrane Vesicles from Normal, Hypothyrold, and Thyroxine-Injected HYPOTHYROID RATS ${ }^{a}$

\begin{tabular}{|c|c|c|c|}
\hline & $\begin{array}{c}\text { Normals } \\
(6-13)\end{array}$ & $\begin{array}{l}\text { Hypothy- } \\
\text { roids (4- } \\
6 \text { ) }\end{array}$ & $\begin{array}{c}\text { Thyroxine- } \\
\text { injected hy- } \\
\text { pothyroids } \\
\quad(4-5)\end{array}$ \\
\hline $\begin{array}{l}\text { Phosphoryla- } \\
\text { tion (nmol } \\
\text { ATP (min'mg } \\
\text { of protein })^{-1} \text { ) }\end{array}$ & $145^{b} \pm 6$ & $77 \pm 9$ & $158^{b} \pm 8$ \\
\hline $\begin{array}{l}\text { Oxidation (na- } \\
\text { tom O } \\
(\mathrm{min} \cdot \mathrm{mg} \text { pro- } \\
\left.\text { tein })^{-1}\right)\end{array}$ & $101 \pm 10$ & $131 \pm 29$ & $131 \pm 24$ \\
\hline $\begin{array}{l}\text { Cytochrome } a \text {. } \\
\text { (pmol/mg of } \\
\text { protein) }\end{array}$ & $551 \pm 36$ & $540 \pm 34$ & $458 \pm 50$ \\
\hline
\end{tabular}

${ }^{a}$ Mitochondria were obtained from the livers of normal, hypothyroid or thyroxine ( $\mathrm{LT}_{4}$ )-injected hypothyroid rats (Spartan, Williamston, Mich.) as described previously (3), and inner membrane vesicles were prepared by digitonin extractions (4). The dose of $\mathrm{LT}_{4}$ was $0.5 \mu \mathrm{g} / \mathrm{g}$ body weight intraperitoneally, and the injected hypothyroid rats were killed 3 days later. Phosphorylation of ADP (5) was measured in

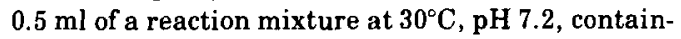
ing $5 \mathrm{~mm} \mathrm{ADP} ; 5 \mathrm{~mm} \mathrm{MgSO}_{4} ; 20 \mathrm{mM}$ Tris-sulfate; 10 mM $\mathrm{P}_{\mathrm{i}}$, containing $10^{6} \mathrm{cpm}$ of ${ }^{32} \mathrm{P}_{\mathrm{i}} ; 20 \mathrm{~mm} \beta$-hydroxybutyrate plus $1.0 \mathrm{mM} \mathrm{NAD}{ }^{+}$, and 5 units of hexokinase (Sigma Type F-300) plus $25 \mathrm{~mm}$ glucose. The reaction was started by adding vesicles containing 0.35-0.5 mg of protein, measured by a biuret method (6). The reaction was stopped after $5 \mathrm{~min}$ by addition of $0.05 \mathrm{ml}$ of $35 \%$ perchloric acid and, after $P_{i}$ was extracted, Cerenkov radiation was measured in a liquid scintillation counter. Oxygen uptake was measured in a $1-\mathrm{ml}$ glass chamber at $30^{\circ} \mathrm{C}$ by using a Clark oxygen electrode and a Gilson Oxygraph. The concentrations of reactants were the same as in the ATP synthesis experiments, except that hexokinase and ADP were omitted; this did not change respiration. Cytochrome $a$ content was determined from difference spectra of oxidized and succinate-reduced vesicles, obtained on a dual-wavelength/split-beam Aminco-Chance spectrophotometer (7). The number of preparations examined is shown in the parentheses. The specified units for each measurement are shown $\pm \mathrm{SE}$.

${ }^{b}$ Significant differences from hypothyroids; $P<$ 0.05 , as calculated from Student's $t$ test.

are both affected by alterations in the unsaturated fatty acids of mitochondrial membranes. We therefore measured the fatty acids in the phospholipids of the inner membrane vesicles. The average total contents of phospholipids per gram of protein appeared to be similar in vesicles from normal and hypothyroid rats, so differences in percentage contents of fatty acids between the two groups represent differences in absolute contents. The relative contents of all the fatty acids, expressed as mole fractions, were affected by the thyroid state of the rats that served as a source of the membrane vesicles. Some fatty acids were at normal levels in vesicles from hypothyroid rats but were changed by $\mathrm{LT}_{4}$ injection; some were at abnormal levels in vesicles of hypothyroid rats but were not changed significantly 3 days after hormone treatment; and some were abnormal in the vesicles of hypothyroid rats and became normal 3 days after the rats were injected with hormone, when phosphorylation was corrected. Those fatty acids in the last group would seem to reflect most directly the effects of hormone deficiency and replacement upon phosphorylation, and their mole fractions together with the total unsaturation index are shown in Table II. In the inner membranes of the mitochondria from the livers of hypothyroid rats, palmitic acid (16:0) and the unsaturated fatty acids linoleic (18:2), linolenic or $\gamma$-linolenic (18:3), and eicosatrienoic (20:3) are increased, and arachidonic $(20: 4)$, docosatrienoic $(22: 3)$, and docosatetraenoic (22:4) are depleted. Although $20: 3$ is normally

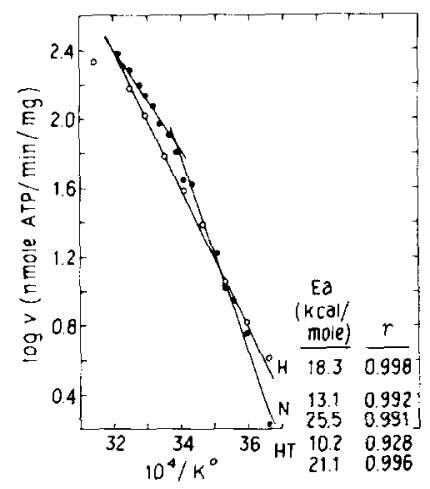

Fig. 1. Arrhenius plot of the rate of phosphorylation of ADP in inner membrane vesicles from normal and hypothyroid rats. The rates of phosphorylation were measured as in Table I, except that the ADP concentration was $2.5 \mathrm{~mm}$. Each point represents the mean of measurements on one to six different batches of mitochondrial vesicles. The slopes for the Arrhenius plots and the position of the inflection were determined by a least-mean-squares method by using various possible two-line fits, with the criterion of the highest correlation coefficients $(r)$. The energies of activation (Ea) and $r$ are shown for vesicles prepared from mitochondria of normal rats (N), hypothyroid rats $(\mathrm{H})$, and hypothyroid rats pretreated with $\mathrm{LT}_{4}$ (thyroxine) as in Table I (HT; the Arrhenius plot is not shown). 
TABLE II

Selected Fatty Acid Contents of Inner Membrane Vesicles from Normal, Hypothyroid, and Thyroxine-InJected HÝpothyroid Rats ${ }^{a}$

\begin{tabular}{|c|c|c|c|}
\hline \multirow{2}{*}{$\begin{array}{l}\text { Fatty } \\
\text { acid }\end{array}$} & \multicolumn{3}{|c|}{ Mole percent $\pm \mathrm{SE}$} \\
\hline & Normals (7) & $\begin{array}{l}\text { Hypothy- } \\
\text { roids }(9)\end{array}$ & $\begin{array}{l}\text { Thyroxine-in } \\
\text { jected hypo- } \\
\text { thyroids (8) }\end{array}$ \\
\hline $16: 0$ & $13.1 \pm 0.4$ & $15.8 \pm 0.6$ & $13.9 \pm 0.7$ \\
\hline $18: 2$ & $18.7 \pm 0.05$ & $25.5 \pm 1.9$ & $15.6 \pm 0.7$ \\
\hline $18: 3$ & 0 & $0.3 \pm 0.03$ & 0 \\
\hline $20: 3$ & $0.1 \pm 0.01$ & $1.0 \pm 0.1$ & $0.3 \pm 0.1$ \\
\hline $20: 4$ & $29.7 \pm 0.5$ & $22.0 \pm 0.6$ & $28.6 \pm 0.5$ \\
\hline $22: 3$ & $0.3 \pm 0.03$ & $0.1 \pm 0.03$ & $(0.2 \pm 0.04)$ \\
\hline $22: 4$ & $2.2 \pm 0.2$ & $1.0 \pm 0.1$ & $2.0 \pm 0.1$ \\
\hline $\begin{array}{c}\text { Unsatu- } \\
\text { ration } \\
\text { index }\end{array}$ & 202.7 & 181.3 & 193.8 \\
\hline
\end{tabular}

${ }^{a}$ Vesicles were prepared as in Table I, and lipids were extracted (15) and esterified by methanolysis (16) in the presence of added internal standard fatty acids (23:0 or 24:0). Cholesterol and hydrocarbons were removed by passage through a Unisil silica gel column. The eluted methyl esters were taken up in carbon disulfide and resolved and quantitated by gas-liquid chromatography (courtesy of Dr. N. Radin). External standards were measured, and the assignment of the number of carbons and unsaturated bonds was checked by mass spectrometry. The unsaturation index was calculated from the mole fractions and the number of unsaturated bonds of all the fatty acids extracted; fatty acids present in amounts less than $0.1 \%$ of the most abundant fatty acid were ignored. As noted in the text, this table shows only the contents of those fatty acids that were abnormal in mitochondrial vesicles prepared from the livers of hypothyroid rats, and that were restored to normal 3 days after injecting hypothyroid rats with thyroxine as in Table I. The number of preparations analyzed is shown in parentheses. All values are significantly different from hypothyroids $(P<0.025)$, except that of $22: 3$ in the injected hypothyroids $(P<0.1)$.

present in only $0.1 \%$ quantity, it increases about 10 fold in the vesicles from hypothyroid rats. Mitochondria (17) and inner membrane vesicles from normal rats do not contain 18:3, and its consistent presence in the inner membranes of the hypothyroids, even at only $0.3 \%$ of the total, together with its disappearance after treatment suggest an unique defect in hypothyroidism. A defect in unsaturation processes, with the accumulation of $18: 3$, has been postulated from measurements of total liver lipids in hypothyroid rats (18). The 18:3 that appears in mitochondrial inner membranes in hypothyroidism is of the same $\omega$ group as the $20: 3$ and $22: 3$, as judged from the linearity of a plot of $\log$ of retention time versus carbon number (19). If these three acids are of the $\omega 6$ group, and the $18: 3$ is $\gamma$-linolenic acid, our findings may be explained by a metabolic block at the hormone-correctible crossover point, the $\Delta 5$-desaturation $20: 3 \rightarrow 20: 4$ and the elongation $20: 3 \rightarrow 22: 3$. The resultant $10 \%$ decrease in total unsaturation, which is mainly due to the contribution of $20: 4$, seems sufficient to account for major changes in the responses of membrane-linked processes to temperature, as judged by studies on synthetic lipid bilayer membranes $(20,21)$.

Although 3 days are required for the hormoneinduced correction of the depressed phosphorylation at $30^{\circ} \mathrm{C}$ in membrane vesicles from treated hypothyroid rats, it is not yet clear whether the correction of the abnormal fatty acid distribution follows the same time course. Such data will be of help in deciding if the abnormal distribution of inner membrane essential fatty acids in hypothyroidism causes the defect in phosphorylation, as it seems to do in nutritional deficiencies $(13,14,22)$.

\section{REFERENCES}

1. Tata, J. R., Ernster, L., Lindberg, O., Arrhenius, E., Pedersen, S., and Hedman, R. (1963) Biochem. .J. 86, 408-428.

2. Носн, F. L. (1968) Arch. Biochem. Biophys. 124, 238-247.

3. Dimino, M. I., Kuras, R. A., McCleary, A. R., ANd Hoch, F. L. (1972) Arch. Biochem. Biophys. 150, 618-623.

4. Hoppel, C., and Conpfr, C. (1969) Arch. Biochem. Biophys. 135, 173-183.

5. Conover, T. E., Prairie, R. L., and Racker, E. (1963) J. Biol. Chem. 238, 2831-2837.

6. Gornall, A. G., Bardawill, C. J., and David, M. W. (1949) J. Biol. Chem. 177, 751-766.

7. Chance, B., ann Williams, G. R. (1956) Advan. Enzymol. 17, 65-134.

8. TAta, J. R. (1964) in Actions of Hormones on Molecular Processes (Litwack, G., and Kritchevsky, D., eds.), pp. 58-131, Wiley, New York.

9. Lee, M. P., and Gear, A. R. L. (1974) J. Biol. Chem, 249, 7541-7549.

10. Kemp, A., Jr., Groot, G. S. P., and Reitsma, H. J. (1969) Biochim. Biophys. Acta 180, 28-34.

11. Lyons, J. M., and Raison, J. K. (1970) Comp. Biochem. Physiol. 37, 405-411.

12. RAison, J. K. (1973) J. Biocnerg. 4, 285 - 309.

13. KLein, P. D., ANd Johnson, R. M. (1954) J. Biol. Chem. 211, 103-110.

14. Haslam, J. M., Prouddock, J. W., and LinNANE, A. W. (1971) J. Bioenerg. 2, 351-370.

15. Folch, J., Lees, M., and Sloane Stanley, G. H. (1957) J. Biol. Chem. 226, 497-509. 
16. Morin, R. J., Bernick, S., Mead, J., ANd AL fin-Slater, R. B. (1962) J. Lipid Res. 3, 432438.

17. Guarnieri, M., and Johnson, R. M. (1970) Advan. Lipid Res, 8, 115-173.

18. Ellefson, R. D., and Mason, H. L. (1964) Endocrinology 75, 179-186.

19. Ackman, R. G. (1962) Nature (London) 194, 970-971.

20. Lyons, J. M., and Asmundson, C. M. (1965) $J$. Amer. Oil Chem. Soc. 12, 1056-1058.

21. Raison, J. K., Lyons, J. M., Mehlhorn, E. J., and Keith, A. D. (1971) J. Biol, Chem. 246, $4034-4040$.

22. Hayashida, T., and Portman, O. W. (1963) $J$. Nutrit. 81, 103-109.

Y.-D. IDA ChEN Frederic L. Hoch

The University of Michigan

Departments of Biological Chemistry and Internal Medicine

7696 Kresge Building

Ann Arbor, Michigan 18104

Received June 19, 1975 